\title{
Drag Reduction of Semi-Trailer Aerodynamic Devices Determined by Two Different Methods
}

\author{
Tomáš SKRÚCANÝ*, Štefánia SEMANOVÁ, Jozef GNAP, Tomasz FIGLUS, Jiři ČUPERA
}

\begin{abstract}
Actual trend in transport is the decreasing of the energy consumption and GHG production. One way how to decrease these two attributes is the reduction of aerodynamic drag using additional aerodynamic devices on semi-trailers. The paper presents the results of their influence measured by using two different methods. The results were obtained by performing coastdown tests and they were compared with outputs obtained by the measurements in the wind tunnel. The driving test consists of the coastdown test on flat straight track protected from the wind impact. The current velocity was measured by the GPS sensor. The vehicle deceleration was used for the acting driving resistances counting - one of them is the air drag - drag coefficient. The results were compared with drag coefficient values examined in a wind tunnel test on a scaled truck model done by authors.
\end{abstract}

Keywords: aerodynamic device; coastdown test; drag resistance; truck and semi-trailer; vehicle

\section{INTRODUCTION}

Over the last years great attention has been paid to the assessment of climate change and extreme weather events' impacts on the society, on several economic sectors and on transportation networks in particular. It is broadly acknowledged that transport constitutes a special field of the overall economic activity. Road freight transport has negative environmental impacts such as energy consumption, carbon dioxide $\left(\mathrm{CO}_{2}\right)$ and other emissions pollution $[1,2]$. The sustainability of the transport system is increasingly becoming a top-priority objective of public administrations at all levels. At strategic levels, these policy objectives are mainly driven by international commitments to reducing greenhouse gas (GHG) emissions [3-5].

Energy intensity and GHG production can be decreased by reduction of vehicle driving resistances - like rolling, slope, acceleration and drag. Drag is the highest resistance force during high velocity movement on highways. Drag depends not only on the front vehicle parts but also the rear parts - mainly edges - influence the drag value [6-9]. The development of new technical solutions for road vehicles (rear aerodynamic devices) brought the results of aerodynamic drag reduction and this fact influences the energy consumption and GHG emissions [10-12].

The legislation conditions in the EU were changed for the better utilisation of rear aerodynamic devices on road vehicles where the vehicle length can be oversized about $0,5 \mathrm{~m}$ in the case of using this equipment. The highest efficiency of the drag reduction reaches the devices with the length of the $2 / 3$ of the vehicle width [13].

Additional aerodynamic rear devices are suitable examples to make road freight transport friendlier to the environment.

Vehicle movement is very variable during the operation. It is dependent on the haulage and operation conditions like actual and average vehicle speed, average slope of the track, atmospheric conditions, actual vehicle mass and driving technique of the driver. The influence of the aerodynamic devices is changed according to the actual mixture of the vehicle driving resistances.
The most often used methods of measurements are aerodynamic tunnel measurement and coastdown tests. These two methods are suitable to determine vehicle air drag $[12,19]$.

Many authors tried to declare devices real influence on the vehicle fuel consumption but it is not possible to make some universal conclusion [12, 13]. These types of measurements are suitable for setting the air drag values but not the fuel consumption.

The best way with the most valuable results is to specify their possible influence for each type of operation (vehicle - track - mass - driver - weather) by evaluating long-term measurements in real operation [14].

\section{METHODOLOGY}

Results of the coastdown tests is the coastdown characteristic of a vehicle - the curve of actual vehicle deceleration. Based on this, it is possible to assess the mechanical condition of the vehicle, chassis settings, influence of used tires, and aerodynamic properties of the vehicle body.

The coastdown test is a test in which a vehicle's running by inertia is slowed down due to the effect of driving resistance from the moment of shifting the neutral position of the transmission device until the moment of reaching the test speed. The test is carried out on the test track.

In spite of the fact that the measurement and evaluation is conducted consistently, the data obtained from a coastdown test contains errors. Therefore, it is necessary to carry out the test repeatedly $[13,14]$.

When calculating the driving resistance based on the ascertained course of deceleration, it is necessary to increase gross vehicle weight by the proportion of rotating masses (such as tires, discs, brake drums, rotating parts of the transmission) to vehicle inertia $[15,16]$.

When applying physical relationships describing the resistances acting on a vehicle while driving without gear engaged, we can express specific resistances by Eq. (1).

$0=o_{f}+o_{X}+o_{V}-o_{a} \pm o_{s}$ 
where $o_{f}$ is specific rolling resistance, $o_{X}$ is specific resistance of vehicle powertrain, $o_{V}$ is specific air resistance, $o_{a}$ is specific acceleration resistance and $o_{s}$ is specific gradient resistance. All specific resistances of vehicle are dimensionless values.

\subsection{Measurement Description}

Standard STN 300554 is valid in the Slovak Republic and it regulates requirements for testing road vehicles in coastdown tests.

The standard applies for determination of the coastdown characteristic of a vehicle and thus related driving resistances. The standard applies to passenger cars, freight vehicles, buses, and combination vehicles.

The standard regulates the conditions relating to the vehicle, the test track, weather conditions, and evaluation of results.

Coastdown tests were carried out to ascertain the aerodynamic drag. The tests were conducted based on the principles of existing standards regulating this type of test and adjusted for appropriate use and achievement of explanatory power of results.

\subsubsection{Vehicle}

The truck with semi-trailer (Fig. 1) was used as a test vehicle. The chosen tested tractor unit was MAN TGX 18.440, EURO 6, XLX cab, with a MEGA semi-trailer (low - profile tires). Dimensions of tractor tires were $315 / 60$ R22.5 at the front axle and 295/60 R22.5 at the rear axle.

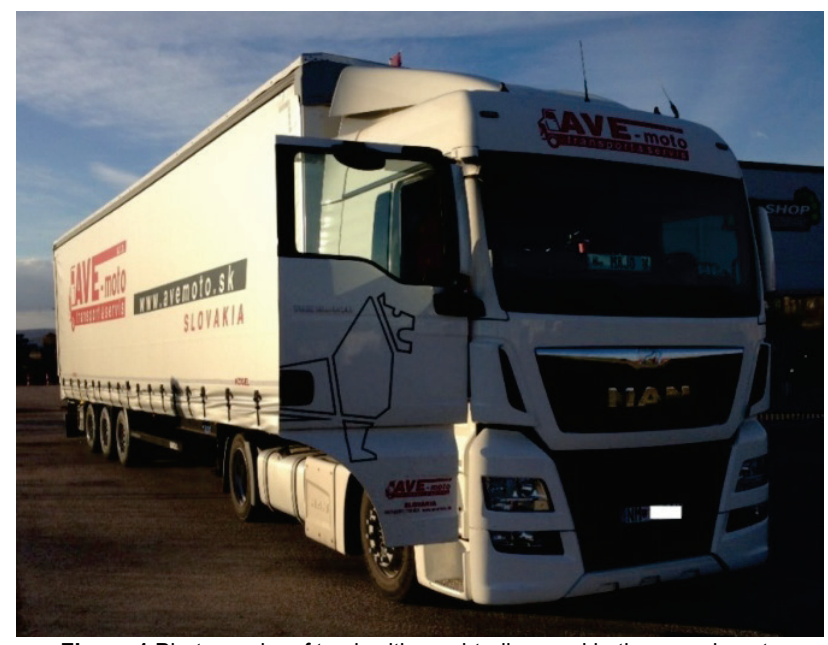

Figure 1 Photography of truck with semi-trailer used in the experiments

A three-axle flatbed curtainside semi-trailer Kögel SNCO with the dimensions of the MEGA version (internal loading height of $3 \mathrm{~m}$ ) and 445/45 R19.5 tires was used as the test semi-trailer.

The combination vehicle (its loading space) was empty during the measurement and the driver and assistants (two persons) working with measuring equipment were in the vehicle cab. The combination vehicle was weighed before the measurement and its weight was 15100 kilograms.

The vehicle was equipped by rear aerodynamic device - rear deflector. This equipment is mounted on the rear semi-trailer door and it can be switched between two states - using and hide (Fig. 5).

\subsubsection{Road Section Used for the Coastdown Tests}

Coastdown tests were carried out on the section of first class road No. I/61 in the district of Nové Mesto nad Váhom (NM), Western Slovakia. This section is located about $1 \mathrm{~km}$ north from the end of the urban area of NM in the direction to Trenčín city (TN). The section $1 \mathrm{~km}$ long was chosen in relation to its location and geometrical parameters. The chosen section of the road is entirely straight and thus the driver did not have to intervene into the driving and thereby change the direction during the test. The roadway is almost horizontal and its longitudinal slope is $0,155 \%$ (the direction to TN). This data was obtained by measuring the height of the roadway by using a levelling instrument. One of the main reasons to choose this section as a test track was the criterion of preventing the influence of wind on the vehicle. The test track is well sheltered from the wind because the track is wind-protected from the north side thanks to the row of trees behind which there is also situated the foothill of "Tureckývrch". From the right side, the track is sheltered by the row of trees as well as by the embankment of the Váh Channel (Fig. 2). These facts enable us to protect the test track against the wind from all directions except the northeast and the southwest. However, the northeast and the southwest wind did not blow during the measurement and thus there were almost windless conditions. These facts were detected by using the anemometer.

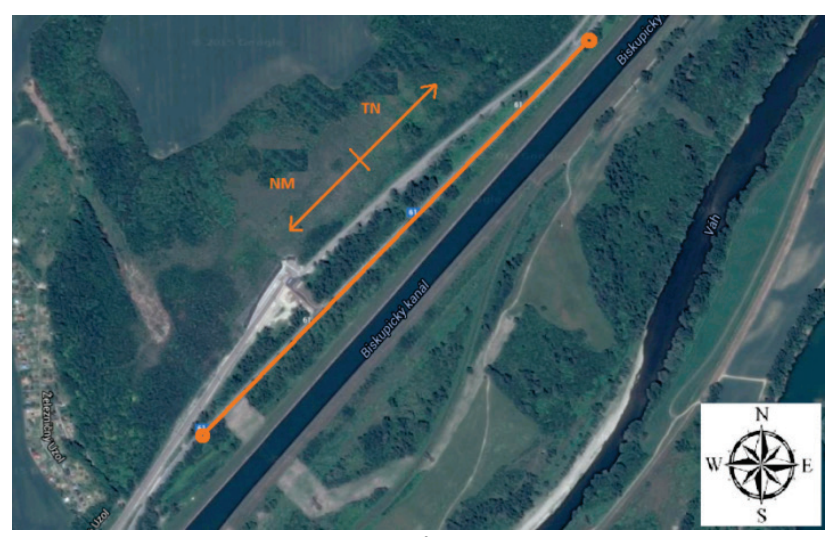

Figure 2 Test track for coastdown tests

\subsubsection{Equipment Used for Measurement}

Several measuring tools were used for the measurement (Fig. 3).

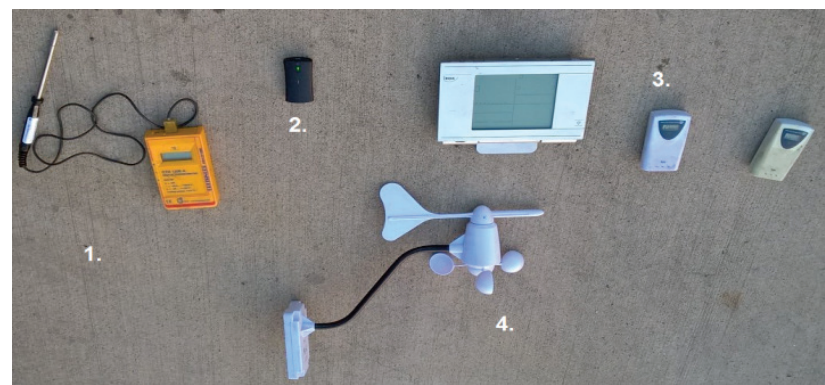

Figure 3 Measuring equipment (1. contact thermometer, 2. GPS sensor, 3. weather station with sensors measuring temperature, humidity and pressure, 4 . anemometer with a wind direction sensor) 
To ascertain the air density or its changes during the measurement it is necessary to monitor the air temperature and atmospheric pressure. The weather station "Weather Capture" can be used for this purpose. Thanks to its external sensors, this device monitors also other variables such as air humidity, the wind strength and direction, rainfall, etc.

To determine the temperature of the vehicle's tires we used a contact thermometer operating on the principle of electrical resistance of a size dependent on the temperature.

The most important parameters of the coastdown test such as instantaneous vehicle speed, time and distance travelled were monitored by using the device operating on the principle of GPS technology - multifunction device.

GPS camera is a driver recording system which uses GPS, GPS/GPRS system and a 3D sensor of acceleration. It is used to record position and instantaneous velocity. This device is powered by a $12-24 \mathrm{~V}$ battery. It is necessary to insert a SD memory card for recording data.

\subsubsection{Procedure}

To obtain results with sufficient explanatory power it is necessary to ensure the most accurate input data of physical variables. For this purpose, measurements were taken of the slope of the test track, weather conditions as well as weighing of the vehicle, wheels and other parts of the powertrain of the vehicle.

Before coastdown tests focusing on determination of the coefficient of drag $C_{d}$ it was necessary to carry out coastdown tests to determine the rolling resistance of wheels and mechanical resistances of the vehicle powertrain. The principle of both types of tests was the same and it represents the measurement of the instantaneous speed of the vehicle during its deceleration from the initial measurement speed down to the specified speed due to driving resistances acting on the vehicle while driving without gear engaged.

The driving resistances acting on the vehicle are expressed in Eq. (1). The rolling resistance, mechanical resistance and drag always act against the vehicle movement whereas the resistance of inertia (the kinetic energy acquired during the vehicle acceleration due to vehicle mass and velocity) acts against deceleration. The gradient resistance may act in the direction of the vehicle movement as well as against the vehicle movement (driving downhill or uphill) [8, 14, 17, 18].

To simplify calculations, we consider only so-called mechanical resistance which includes rolling resistances of tires together with losses in the vehicle powertrain. This means that variables $o_{f}$ and $o_{X}$ in Eq. (1) are replaced with $o_{M}$. Subsequently, we replace $-o_{a}$ with $o_{b}$ (resistance of deceleration) or $b=-a$ (Eq. (2)). Then, the coefficient of drag (Eq. (3)) may be derived from Eq. (2) in the following steps:

$$
\begin{aligned}
& 0=o_{M}+o_{V}+o_{b} \pm o_{s} \\
& 0=f_{M V}+\frac{\rho_{V} \cdot C_{d} \cdot S \cdot v^{2}}{2 \cdot G}+\frac{b}{g} \cdot \delta \pm \frac{s}{100} \\
& 0=\left(f_{M}+0,23 \cdot 10^{-6} \cdot V^{2}\right)+\frac{\rho_{V} \cdot C_{d} \cdot S \cdot v^{2}}{2 \cdot m \cdot g}+\frac{b}{g} \cdot \delta \pm \frac{s}{100}
\end{aligned}
$$

$C_{d}=\frac{2 \cdot\left[\frac{b}{g} \cdot \delta-\left(f_{M}+0,23 \cdot 10^{-6} \cdot V^{2}\right) \pm \frac{s}{100}\right] \cdot m \cdot g}{\rho_{V} \cdot S \cdot v^{2}}$

where $b$ is vehicle deceleration, $\mathrm{m} / \mathrm{s}^{2} ; g$ is acceleration of gravity, $\mathrm{m} / \mathrm{s}^{2} ; \delta$ is coefficient of inertia of rotating masses; $f_{M}$ is coefficient of mechanical resistances; $f_{M V}$ is coefficient of mechanical resistances taking into account vehicle velocity; $V$ is vehicle velocity, $\mathrm{km} / \mathrm{h} ; v$ is vehicle velocity, $\mathrm{m} / \mathrm{s} ; m$ is vehicle mass, $\mathrm{kg} ; \rho_{V}$ is specific air density, $\mathrm{kg} / \mathrm{m}^{3} ; S$ is vehicle frontal area, $\mathrm{m}^{2}$ and $s$ is slope of the roadway, $\%$.

During the measurement, air temperature was stable at $13{ }^{\circ} \mathrm{C}$ and atmospheric pressure was $1015,3 \mathrm{hPa}$ resulting in air density at the level of $1,238 \mathrm{~kg} / \mathrm{m}^{3}$. Measurement of wind, its strength and direction, was carried out with each repetition of the measurement. There was almost windless weather only with light and short-term breeze (lasting several seconds) with the speed of $1 \mathrm{~m} / \mathrm{s}$ during the measurement.

Tire temperature was measured to ensure the same temperature in all repeated measurements. Stability of this temperature was ensured by warming up the vehicle before the test and then by vehicle constant movement during that test. The temperature of the tires measured at several points of their circuit was around $27^{\circ} \mathrm{C}$.

Vehicle frontal area was ascertained by measurement of the vehicle dimensions in the front cross-section. The measured value represented $10,3 \mathrm{~m}^{2}$ after taking into account the empty areas such as blank space between the wing-mirrors, gaps between wheels and the underside of the bumper.

The mass coefficient (effect of inertia of rotating parts) was determined by weighing the individual wheels and the transmission components (half-shafts, differential gear, brake disc, wheel hub, bearings, and cardan shaft). The weight of components which could not be weighed was determined based on the data from catalogues of the suppliers of spare parts. The value of this coefficient represents 1,0615 in case of the gear disengaged $[19,20]$.

Coastdown tests for determination of the actual coefficient of mechanical resistances had to be made before carrying out coastdown tests focusing on determination of the drag coefficient $C_{d}$. Mechanical resistances include rolling resistance and the losses in the vehicle powertrain. Rolling resistance of wheels does not depend only on tire deformation but also on the surface roughness and therefore the rolling resistance is different in relation to different surfaces. To determine the exact mechanical resistances of the vehicle, a series of coastdown tests at low speed was carried out on the test track. After the vehicle reached the initial measurement speed of $15 \mathrm{~km} / \mathrm{h}$, the driver disengaged the gear and the vehicle gradually slowed down till it stopped. At such low speed, the influence of drag could be neglected. After taking into account all remaining input data and the measured deceleration, we determined the resultant mechanical resistance of the tested vehicle on the test track [9, 21, 22]. Four tests in each direction and thus eight measurements in total were carried out. The resultant values of mechanical resistance were determined as an arithmetic average 
separately for each direction and we also determined the total coefficient for both directions at the level of 0,006.

Instantaneous speed was monitored by using TX300 Camera with the frequency of $1 \mathrm{~Hz}$. In terms of a velocity change per time unit ( $1 \mathrm{~s})$, vehicle deceleration was computed at every second of the measurement. Due to nonuniformity of the measurement through GPS signal, it was necessary to slightly correct the values of deceleration (Fig. 4).

\section{RESULTS}

The exponential function was used to eliminate inaccuracies in the measurement of instantaneous speed. It represents a trend line of data series of vehicle speed. Such slight corrections of the course of vehicle speed in the observed road section were used for each measurement repetition. Reliability of $R^{2}$ function ranged from 0,92 to 0,99 . Based on the adjusted speed, the instantaneous deceleration of the vehicle was calculated $[13,10,11]$.

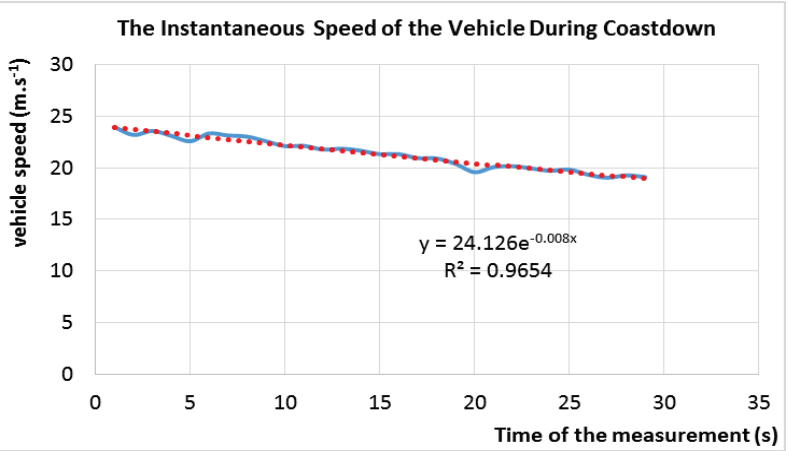

Figure 4 Course of the instantaneous speed of the vehicle during coastdown

To determine the values of drag coefficient it was necessary to carry out coastdown tests at high speed. Obviously, air resistance has the greatest impact among other resistances in the case of high speed, especially over $80 \mathrm{~km} / \mathrm{h}$. Therefore, the initial measurement speed during the coastdown test was as high as possible (maximum vehicle speed was limited by a limiter at the level of 90 $\mathrm{km} / \mathrm{h}$ ) and the end speed, at which the measurement was carried out, was approximately $70 \mathrm{~km} / \mathrm{h}$. Thus, the highest accuracy of measuring the impact of coefficient $C_{d}$ could be achieved and the level of drag for vehicle deceleration was determined [23-26]. The principle of coastdown was the same as in case of the test of mechanical resistances. The driver disengaged the gear and the vehicle gradually slowed down. Compared to the previous type of the test, the vehicle deceleration was measured in the interval of speed $90-70 \mathrm{~km} / \mathrm{h}$ and not till complete stop of the vehicle. Four coastdown tests in each direction and thus eight measurements in total were carried out [27-29]. The resultant values of resistances were determined as an arithmetical average separately for each direction and we also determined the total coefficient for both directions. The results are compared for the measurement with and without the tail deflector (Fig. 5). The results are shown in Tab. 1.

Based on the measured values (Tab. 1), we can observe a decrease of drag coefficient $C_{d}$ from 0,557 to 0,536 when using a tail deflector. If we want to express this in DC units, as the results of measurements in anaerodynamic tunnel (Tab. 2), this represents the reduction by 7 DC. DC units (Drag counts - units of air resistance) represent thousands of times the difference of the coefficients $C_{d}$ for reference vehicle and vehicle with devices. This is a simplified labelling of drag coefficients difference [12, 3032]. However, the value of a drag coefficient is rounded to two decimal places in common practise as well as according to the STN standard for coastdown tests. Therefore, there is also the last right column of Tab. 1 containing those values and there is a decrease from 0,56 to 0,54 .

Table 1 Values of drag coefficient $C_{d}$ measured by coastdown test

\begin{tabular}{|c|c|c|c|c|c|}
\hline \multirow[b]{2}{*}{ State } & \multirow[b]{2}{*}{ Direction } & \multicolumn{4}{|c|}{$C_{d}$} \\
\hline & & \multirow{2}{*}{$\begin{array}{c}\begin{array}{c}\text { One } \\
\text { direction }\end{array} \\
0,537\end{array}$} & $\begin{array}{c}\text { Both } \\
\text { directions }\end{array}$ & \multicolumn{2}{|c|}{ Results } \\
\hline \multirow{4}{*}{$\begin{array}{l}\text { Without aero } \\
\text { - devices }\end{array}$} & $\mathrm{TN}$ & & \multirow{2}{*}{0,559} & \multirow{4}{*}{0,557} & \multirow{4}{*}{0,56} \\
\hline & NM & 0,580 & & & \\
\hline & $\mathrm{TN}$ & 0,538 & \multirow{2}{*}{0,556} & & \\
\hline & NM & 0,574 & & & \\
\hline \multirow{4}{*}{$\begin{array}{l}\text { With aero - } \\
\text { devices }\end{array}$} & $\mathrm{TN}$ & 0,527 & \multirow{2}{*}{0,540} & \multirow{4}{*}{0,536} & \multirow{4}{*}{0,54} \\
\hline & NM & 0,556 & & & \\
\hline & $\mathrm{TN}$ & 0,506 & \multirow{2}{*}{0,530} & & \\
\hline & NM & 0,554 & & & \\
\hline
\end{tabular}

*(TN - northeast direction to Trenčín city, NM - southwest direction to Nové Mesto nad Váhom city)

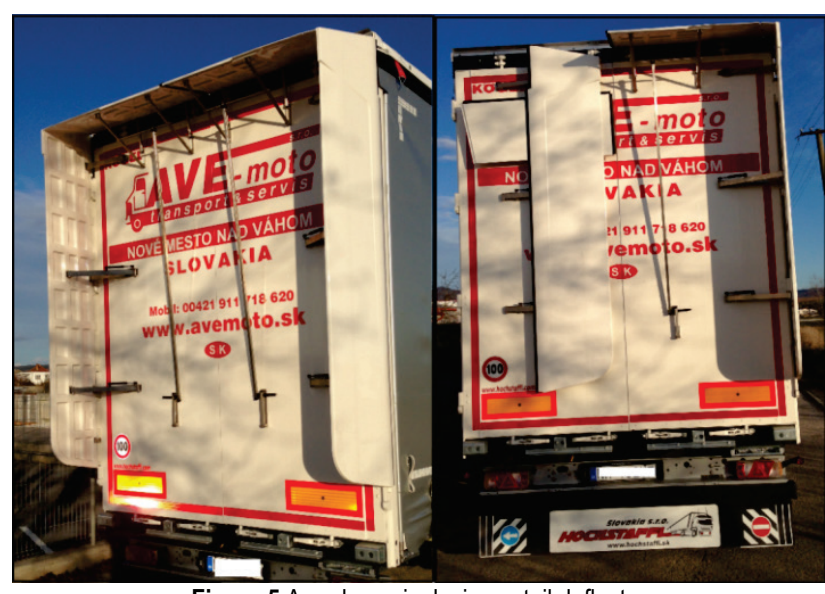

Figure 5 Aerodynamic devices - tail deflector

\section{DISCUSSION}

We compare the results obtained by coastdown tests with those obtained by the measurements in an aerodynamic tunnel [12]. The measurements in the tunnel were carried out with a vehicle model (scale 1/24) for two aerodynamic elements: tail deflector, sealed wheels and their combination (Fig. 6).

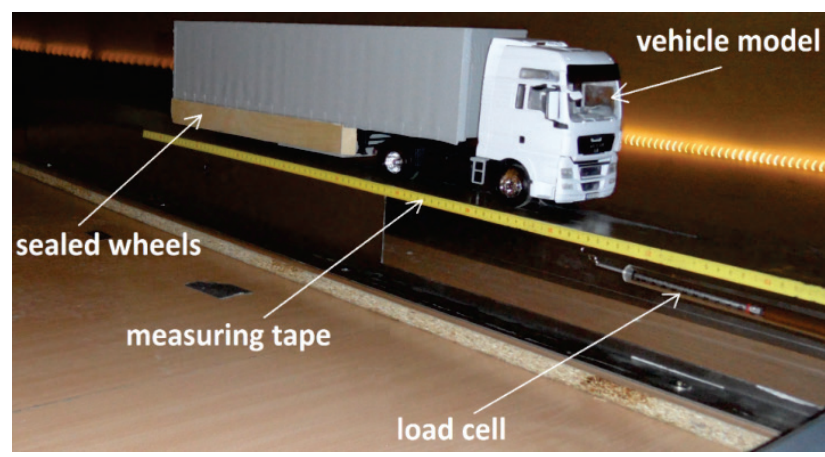

Figure 6 Measuring apparatus (aerodynamic tunnel) [12] 
The tests were carried out for 0 and 5 degrees' yaw angles relative to the aerodynamic tunnel centreline (Tab. 2, Fig. 7). Given the fact that we had available only the tail deflector during the measurements carried out in the selected road section, Tab. 3 compares the results only for a reference model (without any aerodynamic device) and the use of a tail deflector.

Table 2 Evaluation of the values measured in the tunnel [31]

\begin{tabular}{|l|c|c|c|c|c|c|}
\hline \multicolumn{1}{|c|}{ Device } & $\begin{array}{c}C_{d} \text { yaw } \\
0^{\circ}\end{array}$ & $\begin{array}{c}C_{d} \text { yaw } \\
5^{\circ}\end{array}$ & $\begin{array}{c}C_{d} \\
\text { (weigh } \\
- \text { ted) }\end{array}$ & $\begin{array}{c}\mathrm{DC} \\
\text { yaw } 0^{\circ}\end{array}$ & $\begin{array}{c}\mathrm{DC} \\
\text { yaw } 5^{\circ}\end{array}$ & $\begin{array}{c}\mathrm{DC} \\
(\text { weigh }- \\
\text { ted) }\end{array}$ \\
\hline $\begin{array}{l}\text { Reference } \\
\text { model }\end{array}$ & 0,563 & 0,627 & 0,606 & - & - & - \\
\hline $\begin{array}{l}\text { Sealed } \\
\text { wheels }\end{array}$ & 0,521 & 0,606 & 0,578 & -43 & -21 & -28 \\
\hline Tail & 0,521 & 0,620 & 0,587 & -43 & -7 & -19 \\
\hline $\begin{array}{l}\text { Combined } \\
\text { devices }\end{array}$ & 0,479 & 0,570 & 0,540 & -85 & -57 & -66 \\
\hline
\end{tabular}

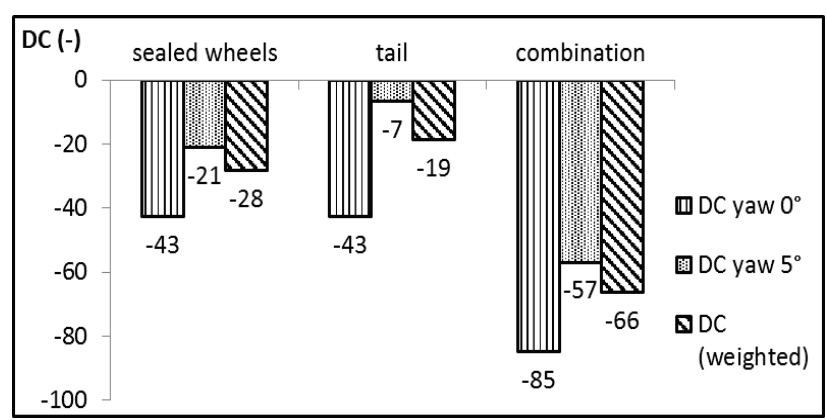

Figure 7 Drag values in DC from the tunnel test [12]

Both measurements (in the aerodynamic tunnel and on the selected road section) showed satisfactory results in terms of the expected values of coefficients considered in common practice and stated by manufacturers. Differences between individual measurements were minimal. In the case of the reference model (without aerodynamic device), the coefficient measured in the tunnel was lower by $1,07 \%$ compared to the coastdown test. When using a tail deflector, the coefficient measured by the coastdown test was higher by $2,88 \%$ compared to the measurement in the tunnel.

Table 3 Comparison of coefficient $C_{d}$ with the use of tail deflector

\begin{tabular}{|l|c|c|c|}
\hline State & $\begin{array}{c}\text { Aerodynamic } \\
\text { tunnel (vehicle } \\
\text { model) } \\
{\left[C_{d}\right]}\end{array}$ & $\begin{array}{c}\text { Coastdown test } \\
\text { (real vehicle) } \\
{\left[C_{d}\right]}\end{array}$ & $\begin{array}{c}\text { Difference } \\
/ \%\end{array}$ \\
\hline Reference model & 0,563 & 0,557 & $-1,07$ \\
\hline Tail deflector & 0,521 & 0,536 & 2,88 \\
\hline Drag reduction in DC & -42 & -21 & - \\
\hline
\end{tabular}

The value of air drag coefficient for the reference vehicle was approximately $0,56 \quad(1,07 \%$ difference between both methods). The usage of aerodynamic devices caused the air drag coefficient reduction from 0,56 to 0,52 (tunnel test) and 0,54 (coastdown test).

The deviation between these resuls on the reference vehicle is $1,07 \%$. This low value can be caused by the small shape differences between the scaled model and real vehicle.

The measurement in the case of the vehicle with the aerodynamic device (tail deflector) showed a deviation of $2,88 \%$. This was caused mainly due to inaccuracy of the additional elements on the vehicle model compared to those on the real vehicle. The exact dimensions of the actual tail deflectors were not known before a process of making own wooden elements. The actual tail deflectors were a little shorter than those on the vehicle model and therefore the effect of directing the airflow was probably smaller and thus the impact on reduction of $C_{d}$ was also smaller. The difference in the construction of tail deflectors is marked with the red circle in Fig. 8.

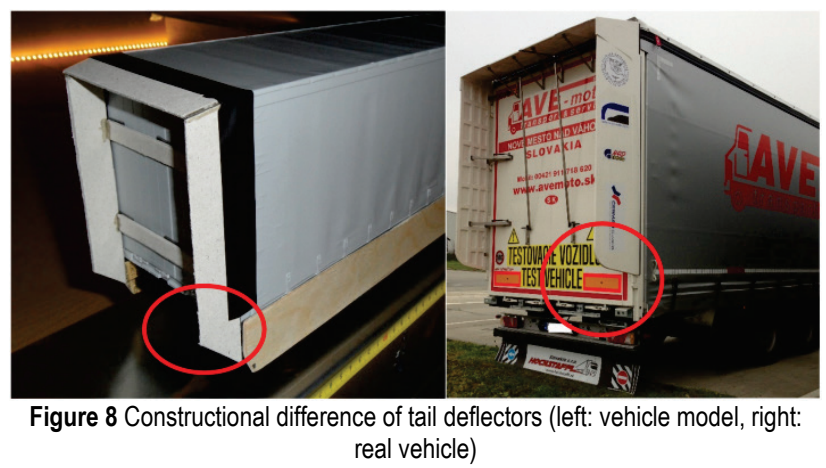

\section{CONCLUSION}

Both measurement methods validate utilisation of aerodynamic rear devices as the suitable way of air drag reduction. Vehicle fuel consumption depends on the value of the vehicle resistances sum. The fuel consumption is decreasing (even disproportional) with air drag reduction. This fact is strongest in the case of high speed operation of the vehicles, e.g. motorway driving. The average vehicle velocity is increasing with increasing of kilometre number of motorway net in whole Europe. This reality causes increasing suitability of the devices usage.

The results of both types demonstrate the explanatory power of results obtained by different methods. Carrying out the measurement with a scale model of a vehicle in an aerodynamic tunnel is a cheaper option and it is less timeconsuming especially at higher number of repetitions However, this is not always the easiest method of measuring. The measurements with a real vehicle are closer to the real conditions, but the obtained results may be influenced by ambient conditions such as weather effects, the technical condition of vehicles and so on. The results published in this paper demonstrate drag reduction in the case of tested vehicles. The results also show the possibility of further testing of additional aerodynamic elements in terms of the issue of fuel consumption reduction.

\section{Acknowledgements}

This publication is the result of two project funds:

1) Centre of excellence for systems and services of intelligent transport, ITMS 26220120028 supported by the Research Agency, Research and Development Operational Programme funded by the ERDF (European Regional Development Fund). "Podporujeme výskumné aktivity na Slovensku/Projekt je spolufinancovaný zo zdrojov EÚ". "We support research activities in Slovakia/Project is co-financed by EU sources". 
2) Institutional project of Department of Road and Urban Transport, University of Žilina, "Vplyv aerodynamických vlastností vozidiel $\mathrm{v}$ cestnej depravena ich prevádzku" (Influence of aerodynamical characteristics on road vehicle operation, 6/KCMD/2018.

\section{REFERENCES}

[1] Csiszár, C. \& Földes, D. (2018). System Model for Autonomous Road Freight Transportation. Promet - Traffic \& Transportation, 30(1), 97-103. https://doi.org/10.7307/ptt.v30i1.2566

[2] Polcar, A., Cupera, J., \& Sedlak, P. (2014). Exhaust Emissions of Spark-Ignition Engine Fuelled by E85. Listycukrovarnické a řepařské, 130(4), 149-153.

[3] Barmaki, R., Ilkhani, M., \& Salehpour, S. (2016). Investigation of Energy Usage and Emissions on Plug-In and Hybrid Electric Vehicle. Tehnički vjesnik, 23(3), 899-906. https://doi.org/10.17559/TV-20140928112417

[4] Barta, D., Mruzek, M., Kendra, M., Kordos, P., \& Krzywonos, L. (2016). Using of Non-Conventional Fuels in Hybrid Vehicle Drives. Advances in Science and Technology Research Journal, 10(32), 240-247. https://doi.org/10.12913/22998624/65108

[5] Skrucany, T., Kendra, M., Stopka, O., Milojevic, S., Figlus, T., \& Csiszár, C. (2019). Impact of the Electric Mobility Implementation on the Greenhouse Gases Production in Central European Countries. Sustainability, 18, 1-15. https://doi.org/10.3390/su11184948

[6] Altaf, A., Omar, A. O., \& Asrar, W. (2014). Passive drag reduction of square back road vehicles. Journal of Wind Engineering and Industrial Aerodynamics, 134, 30-43. https://doi.org/10.1016/j.jweia.2014.08.006

[7] Barth, M. \& Boriboonsomsin, K. (2009). Energy and Emissions Impacts of a Freeway-Based Dynamic EcoDriving System. Transportation Research, Part D: Transport and Environment, 14(6), 400-410. https://doi.org/10.1016/j.trd.2009.01.004

[8] Van der Krieke, J. \& Van Raemdonck, G. (2014). Analyzing Fuel Savings of an Aerodynamic Drag Reduction Device with the Aid of a Robust Linear Least Squares Method. SAE Int. J. Commer. Veh., 7(2). https://doi.org/10.4271/2014-01-2450

[9] McNally, J., Fernandez, E., Robertson, G., Kumar, R., Taira, K., Alvi, F., Yamaguchi, Y., \& Murayama, K. (2015). Drag reduction on a flat-back ground vehicle with active flow control. Journal of Wind Engineering and Industrial Aerodynamics, 145, 292-303. https://doi.org/10.1016/j.jweia.2015.03.006

[10] Choi, H., Lee, J., \& Park, H. (2014). Aerodynamics of Heavy Vehicles. Annual Review of Fluid Mechanics, 46, 441-468. https://doi.org/10.1146/annurev-fluid-011212-140616

[11] Rahimi-Ajdadi, F. \& Abbaspour-Gilandeh, Y. (2011). Artificial Neural Network and stepwise multiple range regression methods for prediction of tractor fuel consumption. Measurement, 44, 2104-2111. https://doi.org/10.1016/j.measurement.2011.08.006

[12] Skrucany, T., Sarkan, B., \& Gnap, J. (2016). Influence of Aerodynamic Trailer Devices on Dragreduction Measured in a Wind Tunnel. Eksploatacjainiezawodnosc - Maintenance and reliability, $18(1), 151-154$. https://doi.org/10.17531/ein.2016.1.20

[13] Hakansson, C. \& Lenngren, M. J. (2010). CFD Analysis of Aerodynamic Trailer Devices for Drag Reduction of Heavy Duty Trucks. Chalmers University of Technology, Goteborg.

[14] Skrucany, T., Figlus, T., Abramović, B., Cupera, J., \& Csiszár, C. (2018). Influence of Vehicle Aerodynamical Devices on Fuel Consumption Evaluated Using Telematics
Tools. $8^{\text {th }}$ International Scientific Conference CMDTUR, 384-392.

[15] Naderipour, M. \& Alinaghian, M. (2016). Measurement, evaluation and minimization of $\mathrm{CO} 2, \mathrm{NOx}$, and $\mathrm{CO}$ emissions in the open time dependent vehicle routing problem. Measurement, 90, 443-452. https://doi.org/10.1016/j.measurement.2016.04.043

[16] Rajamani, R. (2012). Vehicle dynamics and control. Springer, New York. https://doi.org/10.1007/978-1-4614-1433-9

[17] Jereb, B., Kumperščak, S., \& Bratina, T. (2018). Factors Influencing the Purchasing Decisions of Low Emission Cars: A Study of Slovenia. FME Transactions, 46(2), 278-284. https://doi.org/10.5937/fmet1802278J

[18] Wong, J. Y. (2001). Theory of ground vehicles. John Wiley\&Sons. Inc., Ottawa

[19] Hausberger, S., Rexeis, M., Blassnegger, J., \& Silberholz, G. (2011). Evaluation of fuel efficiency improvements in the Heavy-Duty Vehicle (HDV) sector from improved trailer and tire designs by application of a new test procedure. TU Graz, Graz.

[20] Liscak, S., Rievaj, V., \& Sulgan, M. (2008). Vehicle's Technical Condition and Emission. Eksploatacja $i$ Niezawodnosc - Maintenance and Reliability, 37(1), 61-63.

[21] Parczewski, K. \& Wnenk, H. (2013). Using mobile scaled vehicle to investigate the truck lateral stability. Eskploatacja i Niezawodnosc - Maintanence and Reliability, 4, 414-420.

[22] Watkins, S. (1990). Wind-Tunnel Modelling of Vehicle Aerodynamics: with emphasis on turbulent wind effects on commercial vehicle drag. Victorian University of Technology, Melbourne.

[23] Barnard, R. H. (2001). Road vehicle aerodynamic design an introduction. St. Albans: Mechaero Publishing.

[24] Fontaras, G. et al. (2014). An Experimental Methodology for Measuring of Aerodynamic Resistances of Heavy Duty Vehicles in the Framework of European $\mathrm{CO}_{2}$ Emissions Monitoring Scheme. SAE Int. J. Commer. Veh. 7(1). https://doi.org/10.4271/2014-01-0595

[25] Chowdhurya, H., Loganathana, B., Mustarya, I., Moriab, H., \& Alama, F. (2017). Effect of various deflectors on drag reduction for trucks. Energy Procedia, 110, 561-566. https://doi.org/10.1016/j.egypro.2017.03.185

[26] Gunes, D. (2010). On the similarity of wind tunnel experiments and numerical simulation of heavy-duty trailer flow. Progress in Computational Fluid Dynamics, 10(3), 168-176. https://doi.org/10.1504/PCFD.2010.033328

[27] Vrabel, J., Jagelcak, J., Zamecnik, J., Caban, J. (2017). Influence of Emergency Braking on Changes of the Axle Load of Vehicles Transporting Solid Bulk Substrates. Proceedia Engineering, 187, 89-99. https://doi.org/10.1016/j.proeng.2017.04.354

[28] Davila, A. (2013). Report on Fuel Consumption. Project 233683 SARTRE, ECE

[29] Jazar, R. (2009). Vehicle Dynamics, Theory and applications. Springer Science + Bussines Media

[30] Rievaj, V. et al. (2016). The Impact of Air Resistance on the Fuel Consumption in Real Conditions within the Transport Operation. Communications - Scientific Letters of the University of Žilina, 18(2), 57-61.

[31] Holt, J., Garry, K., \& Velikov, S. (2015). A wind tunnel investigation into the effects of roof curvature on the aerodynamic drag experienced by a light goods vehicle. International Journal of Vehicle Design, 67(1), 45-62. https://doi.org/10.1504/IJVD.2015.066478

[32] Hubova, O., Konecna, L., \& Lobotka, P. (2014). Influence of Walls and Ceiling on a Wind Flow in BLWT Tunnel. Applied Mechanics and Materials, 617, 257-262. https://doi.org/10.4028/www.scientific.net/AMM.617.257

[33] Caban, J., Droździel, P., Vrábel, J., Šarkan, B., Marczuk, A., Krzywonos, L., \& Rybicka, I. (2016). The Research on 
Ageing of Glycol-Based Brake Fluids. Advances in Science and Technology Research Journal, 10(32), 9-16. https://doi.org/10.12913/22998624/65113

[34] Hubova, O., Macak, M., Konecna, L., \& Ciglan, G. (2017). External Pressure Coefficients on the Atypical High-Rise Building-Computing Simulation andMeasurements in Wind Tunnel. Procedia Engineering, 190, 488-495. https://doi.org/10.1016/j.proeng.2017.05.368

[35] Stopka, O., Zitricky, V., Abramovic, B., Marinov, M., \& Ricci, S. (2019). Innovative Technologies for Sustainable Passenger Transport. Journal of Advanced Transportation, 2019, 2. https://doi.org/10.1155/2019/4197246

[36] Taranović, D., Ninković, D., Davinić, A., Pešić, R., Glišović, J., \& Milojević, S. (2017). Valve Dynamics in Reciprocating Compressors for Motor Vehicles. Tehnički vjesnik, 24(2), 313-319. https://doi.org/10.17559/TV-20151117130112

[37] Szczucka-Lasota, B., Kamińska, J., \& Krzyżewska, I. (2019). Influence of Tire Pressure on Fuel Consumption in Trucks with Installed Tire Pressure Monitoring System (TPMS). Scientific Journal of Silesian University of Technology, Series Transport, 103, 167-181. https://doi.org/10.20858/sjsutst.2019.103.13

[38] Bisták, M., Brumerčík, F., \& Lukáč, M. (2017). Weighing Systems in Traffic. Scientific Journal of Silesian University of Technology. Series Transport, 93, 5-15. https://doi.org/10.20858/sjsutst.2017.97.1

\section{Contact information}

Tomáš SKRÚCANÝ, Ing., PhD

(Corresponding author)

University of Zilina,

Univerzitna 1, 010 26, Zilina, Slovakia

E-mail: tomas.skrucany@fpedas.uniza.sk

Štefánia SEMANOVÁ, Ing., PhD

University of Zilina,

Univerzitna 1, 010 26, Zilina, Slovakia

E-mail: stefania.semanova@fpedas.uniza.sk

Jozef GNAP, prof., Ing., PhD

University of Zilina,

Univerzitna 1, 010 26, Zilina, Slovakia

E-mail: jozef.gnap@fpedas.uniza.sk

Tomsz FIGLUS, PhD, DSc, Eng, Assoc. Prof.

The Silesian University of Technology,

8 Krasinskiego Street, Katowice 40-019, Poland

E-mail: tomasz.figlus@polsl.pl

Jiří ČUPERA, doc., Ing., PhD

Mendel University of Brno

Zemědělská 1, 61300 Brno, Czech Republic

E-mail: jiri.cupera@mendelu.cz 